\title{
Pemilihan Strategi dan Sarana Promosi Berdasarkan Perilaku Konsumen untuk Peningkatan Penjualan Online yang Dirintis Orang Muda Katolik Di Yogyakarta
}

\author{
Budi Sutedjo Dharma Oetomo ${ }^{1}$, Singgih Santoso ${ }^{2}$ \\ ${ }^{1}$ Program Studi Sistem Informasi, Fakultas Teknologi Informasi, Universitas Kristen Duta Wacana \\ Jl. Dr. Wahidin Sudirohusodo 5-25, Yogyakarta \\ ${ }^{1}$ Email: budi@staff.ukdw.ac.id \\ ${ }^{2}$ Program Studi Manajemen, Fakultas Bisnis, Universitas Kristen Duta Wacana \\ Jl. Dr. Wahidin Sudirohusodo 5-25, Yogyakarta \\ ${ }^{2}$ Email:singgih.santoso@gmail.com
}

\begin{abstract}
Abstrak - Orang-orang muda Katolik di Yogyakarta telah berani melangkah untuk membuat rintisan usaha online, tetapi mereka masih belum mampu mengidentifikasi konsumen sasaran sebagai dasar pemilihan strategi dan sarana promosi yang sesuai. Program pengabdian kepada masyarakat ini bertujuan memberikan wawasan untuk pemilihan strategi dan sarana promosi yang sesuai dengan perilaku konsumen sasaran, agar penjualan online yang telah mereka rintis meningkat. Metode yang diterapkan meliputi pemberian motivasi, pembelajaran, konsultasi dan bimbingan, evaluasi dan perbaikan, serta sharing yang dikemas dalam bentuk webinar bersama para praktisi dan akademisi. Kegiatan ini berhasil membangun kesadaran dan menambah wawasan peserta tentang pentingnya identifikasi perilaku konsumen sasaran. Fakta menunjukkan bahwa penyertaan praktisi mempengaruhi animo pendaftaran, karena peserta membutuhkan contoh dan inspirasi di tataran praktis, selain konsep dan teori. Kegiatan ini sangat bermanfaat untuk meningkatkan kesadaran dan literasi peserta tentang perilaku konsumen sasaran dalam pemilihan strategi dan sarana promosi. Kegiatan ini memperkaya bahan ajar dari matakuliah e-Commerce dan Kewirausahaan berbasis Teknologi Informasi di Program Studi Informatika dan Sistem Informasi, serta matakuliah Pemasaran Digital dan Perilaku Konsumen di Program Studi Manajemen Universitas Kristen Duta Wacana khususnya dan di pelbagai perguruan tinggi pada umumnya.
\end{abstract}

Kata kunci-berbagi pengetahuan praktisi, pemilihan sarana promosi, pemilihan strategi promosi, penjualan online, perilaku konsumen online.

\begin{abstract}
Young Catholics in Yogyakarta have dared to step up to start an online business, but they are still not able to identify target consumers as the basis for selecting target market and appropriate promotional strategies. This community service program aims to provide insight into the selection of promotional strategies and tools that are in accordance with the behavior of target consumers, so they can increase their online sales. The methods applied include providing motivation, learning, consultation and guidance, evaluation and improvement, as well as sharing experinces in the form of webinars with practitioners and academics. This activity succeeded in building awareness and broadening participants' knowledge about the importance of identifying target market behavior. The fact shows that the participation of practitioners affects the enthusiasm for registration, because participants need examples and inspiration at the practical level, in addition to concepts and theories. This activity is very useful for increasing participants' awareness and literacy about the behavior of target consumers in the selection of promotional strategies. This activity enriches eCommerce and Information Technology-based Entrepreneurship teaching materials courses at the Information Systems Study Program, as well as Digital Marketing and Consumer Behavior courses at the Duta Wacana Christian University Management Study Program in particular and at various universities in general.
\end{abstract}

Keywords - practitioner knowledge sharing, promotional tools selection, promotion strategies selection, online sales, online consumer behavior. 


\section{Pendahuluan}

Di Indonesia, pandemi Covid-19 telah berlangsung hampir satu tahun sejak diumumkan oleh Presiden Joko Widodo pada tanggal 2 Maret 2020[1]. Sejak saat itu, aneka kebijakan pembatasan sosial dirumuskan dan diterapkan oleh pemerintah demi menjaga keselamatan dan kesehatan masyarakat. Kebijakan pemerintah tersebut juga diterapkan di lingkup Daerah Istimewa Yogyakata (DIY).

Pandemi Covid 19 telah berdampak luas terhadap perekonomian masyarakat DIY yang bertumpu pada ikon kota Pendidikan dan Pariwisata. Berdasarkan survei Asosiasi Perguruan Tinggi Swasta Indonesia (APTISI) DIY di 51 PTS, tercatat total mahasiswa sebanyak 142.219 mahasiswa aktif yang terdiri dari 57.334 berasal dari dalam dan 84.885 dari luar DIY. Sementara itu, 61.957 mahasiswa yang berasal dari luar DIY telah meninggalkan DIY untuk kembali ke daerah asalnya masing-masing [2]. Sementara itu, di sektor pariwisata, Kepala Dinas Pariwisata DIY Singgih Rahardjo mengungkapkan bahwa jumlah wisatawan yang berkunjung ke DIY mengalami penurunan drastis dibandingkan dengan jumlah wisatawan di tahun 2019[3].

Banyaknya mahasiswa pendatang yang pulang ke daerah asalnya telah membuat masyarakat yang menumpukan penghasilan dari kos-kosan, warung makan, jasa fotocopy, perlengkapan kuliah, dan aneka usaha lainnya yang terkait dengan kebutuhan hidup mahasiswa tersebut mengalami kemerosotan pendapatan. Demikian pula dengan masyarakat yang menumpukan penghasilan dari usaha terkait dengan bidang pariwisata pun mengalami penurunan drastis seiring dengan menurunnya jumlah wisatawan yang berkunjung ke DIY.

Pandemi tersebut telah menjadi salah satu pemicu terjadinya distrupsi yang sangat hebat [4] [5]. Dimana, saat pembatasan sosial dilakukan, maka terjadi perubahaanperubahan dan pergeseran-pergeseran kebutuhan masyarakat yang akhirnya memaksa terjadinya transformasi usaha secara besar-besaran. Salah satu bentuk nyata dari distrupsi besar yang terjadi, yaitu pemanfaatan Teknologi Informasi sebagai sarana usaha yang dikenal dengan istilah usaha rintisan atau startup business[6].

Kondisi itu telah mendorong orang-orang muda yang notabene juga anak-anak dari keluarga-keluarga yang terimbas oleh dampak pandemi Covid-19 itu untuk mengambil inisiatif merintis usaha online dengan mamanfaatkan kemajuan Teknologi Informasi yang berada dalam "genggaman"-nya [7]. Mereka telah berinisiatif untuk memulai usaha online itu, walaupun literasi dan pengetahuan yang tentang perencanaan usaha, perilaku konsumen, pemasaran, promosi dan pengetahuan lain terkait pengembangan usaha online masih sangat terbatas [8].

Oleh karena itu, orang-orang muda Katolik yang tergabung dalam wadah pembinaan dari Badan Pelayanan
Pembaruan Karismatik Katolik (BP PKK) Kevikepan DIY dan Sekolah Evangelisasi Pribadi Eksekutif (SEPex) Muda Yogyakarta sangat membutuhkan pelatihan, pendampingan dan pembinaan. Keingintahuan mereka untuk meningkatkan literasi dan berlatih tidak sekedar untuk memajukan usaha rintisannya semata, tetapi keinginan mereka itu dipicu oleh visi untuk menciptakan lapangan kerja sebagai wujud evangelisasi (pewartaan kabar sukacita dari Allah) dalam bentuk penciptaan lapangan kerja demi peningkatan kesejahteraan hidup masyarakat.

Ketidakpahaman mereka dalam penyusunan rencana usaha rintisan telah terjawab dengan program pengabdian kepada masyarakat LPPM UKDW periode tahun 2020 tentang penyusunan perencanaan usaha rintisan (startup business plan) yang menjadi langkah awal dalam membangun pondasi dan arah pertumbuhan usaha rintisan yang dibangun [9]. Selanjutnya di tahun 2021 ini, mereka membutuhkan program untuk berlatih dalam hal pemilihan strategi dan sarana promosi yang sesuai dengan perilaku konsumen sasaran untuk meningkatkan penjualan dari usaha online tersebut. Kebutuhan pelatihan dan pendampingan tersebut timbul mengingat bila tingkat penjualan tidak bertambah secara signifikan, maka mereka tidak dapat mempertahankan usahanya di tengah persaingan yang sangat kompetitif (hypercompetition)di pasar online [10][11].

\section{PERMASALAHAN}

Tidak sedikit orang muda yang bergerak secara spontan untuk menanggapi situasi dan kondisi pada jamannya. Walaupun dari segi literasi masih terbatas, tetapi orangorang muda telah memiliki niat atau kemauan yang kuat untuk terus belajar dan berlatih, agar mereka dapat mengalami kemajuan dan memecahkan aneka hambatan dan tantangan yang dihadapinya.

Tidak terkecuali, orang-orang muda yang tergabung dalam komunitas-komunitas mitra yang telah berani melangkah untuk membuat rintisan usaha online baik karena untuk menopang penurunan pendapatan keluarga yang terimbas penurunan jumlah mahasiswa dari luar yang tinggal di DIY, serta merosotnya jumlah wisatawan, maupun kesadaran untuk membuka usaha demi menciptakan lapangan kerja baru. Dengan semangat, sekali melangkah pantang menyerah, maka mereka terus berusaha untuk memahami permasalahan-permasalahan yang dihadapi dan berusaha untuk memecahkan dengan bantuan dari berbagai pihak

Setelah berlatih untuk menyusun perencanaan usaha rintisan pada tahun 2020 yang lalu, selanjutnya mereka dihadapkan pada permasalahan tentang peningkatan penjualan. Bilamana penjualan bulanan tidak dapat mencapai target minimal, maka mereka tidak memiliki dana untuk menutup biaya operasional, apalagi biaya pengembangan usaha. 
Oleh karena itu, orang-orang muda Katolik yang tergabung dalam komunitas-komunitas mitra itu membutuhkan pengetahuan, literasi dan pelatihan dan pendampingan untuk peningkatan penjualan. Namun, peningkatan penjualan tidak hanya terkait dengan permasalahan pemilihan strategi dan sarana promosi semata, tetapi juga pemahaman tentang perilaku konsumen sasaran. Jika pilihan strategi dan sarana promosi tidak memperhatikan perilaku konsumen sasaran, maka upaya promosi yang dilakukan hanya akan membuang energi dan dana tanpa dampak yang berarti. Jadi kesesusaian antara pilihan strategi dan sarana promosi dengan perilaku konsumen sasaran sangat menentukan keberhasilan dalam meningkatkan penjualan.

Dalam kaitan itulah, maka orang-orang muda Katolik yang tergabung dan berelasi dengan komunitas-komunitas mitra itu membutuhkan motivasi dan semangat, pengetahuan dan pengalaman praktis di lapangan, konsultasi dan bimbingan, evaluasi dan perbaikan dalam memilih strategi dan sarana promosi yang sesuai dengan perilaku konsumen sasaran, agar mereka dapat meningkatkan penjualan dari usaha online yang dirintisnya.

\section{METODE PELAKSANAAN}

Untuk menjawab kebutuhan mitra, maka kegiatan pengabdian masyarakat ini akan menerapkan kombinasi dari beberapa metode dalam pelaksanaan, agar tujuan para mitra dapat tercapai. Adapun beberapa metode tersebut, yaitu:

\section{A. Pemberian motivasi}

Metode pemberian motivasi [12] ini diterapkan untuk membangkitkan motivasi para peserta dalam mengidentifikasi, memilih dan menerapkan strategi dan sarana promosi, serta konsumen sasaran, karena pemilihan strategi dan sarana promosi yang tepat dibutuhkan kecermatan, ketelitian, ketekunan dan pertimbangan-pertimbangan yang matang untuk mendeteksi seluruh faktor yang terkait, menggali datadata pendukung, melakukan perhitungan dengan cermat, serta membuat keputusan secara bijak. Pemberian motivasi ini dilakukan oleh praktisi dalam bidangnya, yaitu Matius Ekaprasetya selaku Senior Manager PT Enseval grup PT Kalbe Farma dan Erick Kurniawan selaku Microsoft MPV dengan cara berbagi pengalaman dalam mengamati dan mengenali konsumen (Gambar 1).

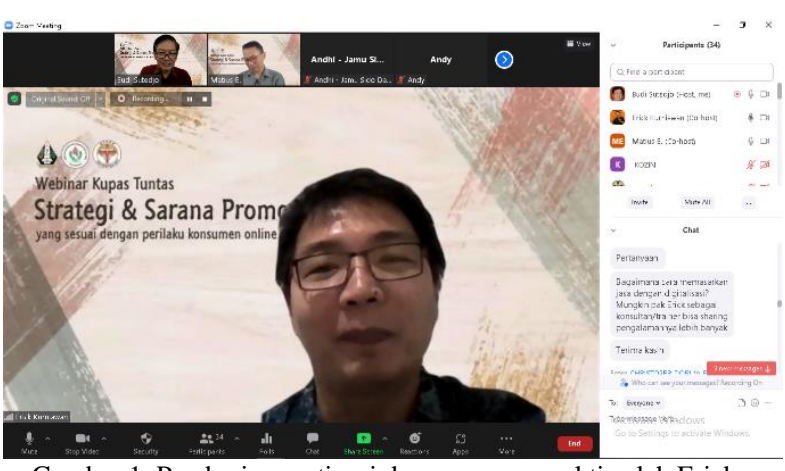

Gambar 1. Pemberian motivasi dan wawasan praktis oleh Erick Kurniawan

B. Pembelajaran langsung

Metode pembelajaran langsung [13] ini diterapkan untuk memberikan bekal kognitif berupa informasi dan pengetahuan fundamental terkait dengan pemilihan strategi dan sarana promosi, serta perilaku konsumen. Peserta diberi wawasan tentang konsep dasar strategi dan karakter-karakter sarana promosi, serta cara untuk mengidentifikasi perilaku konsumen sasarannya. Selain itu, peserta diberi contoh-contoh penerapan, agar mereka dapat memilih strategi dan sarana promosi yang sesuai dengan perilaku konsumen sasarannya. Pembelajaran ini dilakukan oleh para narasumber praktisi, beserta seorang akademisi yang ahli dalam bidang pemasaran, yaitu Dr. Singgih Santoso, SE., MM (Gambar 2).
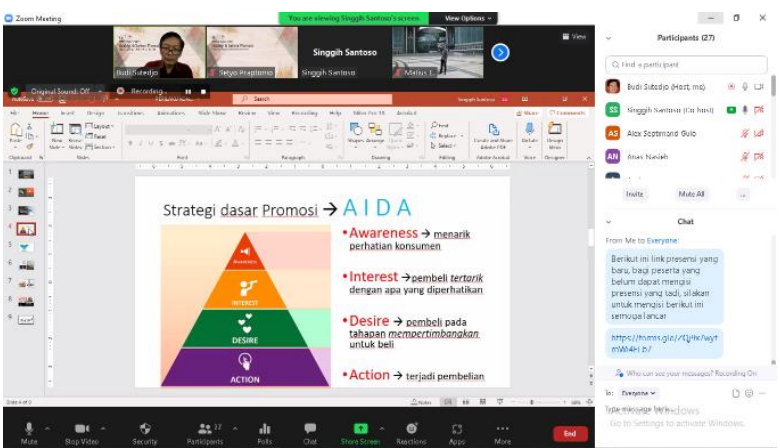

Gambar 2. Pembelajaran bersama narasumber akademisi

C. Konsultasi dan Bimbingan

Metode konsultasi dan bimbingan ini diterapkan untuk memberi masukan bagi peserta yang mengungkapkan pengalaman atau pemikirannya dalam melakukan pemilihan strategi dan sarana promosi secara online terkait dengan usaha yang dikembangkannya. Sebagian peserta memanfaatkan kesempatan untuk konsultasi dan bimbingan dengan para narasumber secara langsung dalam webinar online tersebut (Gambar 3). Umumnya, mereka hanya mengandalkan strategi diskon harga, sehingga margin keuntungan mereka sangat kecil. Akibatnya mereka tidak memiliki budget 
untuk berkreasi atau berinovasi guna mengembangkan cara, desain dan sarana promosi yang digunakannya.

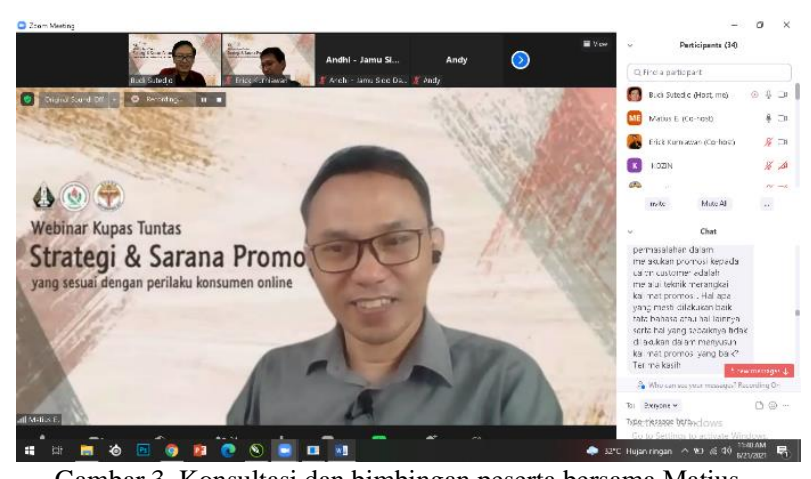

Gambar 3. Konsultasi dan bimbingan peserta bersama Matius Ekaprasetya

D. Evaluasi dan perbaikan

Metode evaluasi dan perbaikan ini diterapkan untuk memberikan umpan balik terhadap rancangan strategi dan sarana promosi yang dipikirkan peserta, agar mereka dapat mengetahui kemungkinan masih adanya kelemahan dan kekurangan dari pilihan strategi dan sarana promosinya, serta upaya-upaya untuk melakukan penyesuaian dengan karakter dan jenis usaha online yang dirintisnya. Umumnya, peserta mau berubah cara dalam memilih strategi dan sarana, serta konten promosi, tetapi sebagian di antara mereka masih terkungkung pada strategi diskon harga, karena hal itu dapat dilakukan dengan mudah, cepat dan memberikan dampak langsung untuk meningkatkan minat beli konsumen. Hampir 50\% peserta dapat melihat adanya konsumen sasaran baru yang dapat dibidik yang selama ini sama sekali belum diperhitungkan. Sementara itu, untuk penerapan strategi-strategi berupa penyajian review dan testimoni konsumen, kerjasama dengan influencer, respon yang cepat, pembentukan komunitas, penguatan merek (brand), memperbanyak penyajian gambar dan video (Tik-Tok) atau animasi, serta penggunaan aplikasi-aplikasi yang diproduksi Microsoft, peserta masih perlu waktu penyesuaian, khususnya dari segi persiapan sumber daya manusia yang akan menanganinya.

\section{E. Sharing}

Metode sharing ini diterapkan untuk memberikan kesempatan bagi peserta untuk berbagi pengalaman untuk mengidentifikasi, mempertimbangkan dan memilih strategi dan sarana promosi yang dilakukannya. Peserta yang mempresentasikan pengalamannya itu juga terbuka untuk menceritakan hambatan dan kegagalan dalam menerapkan strategi dan menggunakan media promosi sebelumnya, sehingga sharing itu meningkatkan pengetahuan peserta, sekaligus sharing itu menjadi bahan diskusi bersama (Gambar 4).

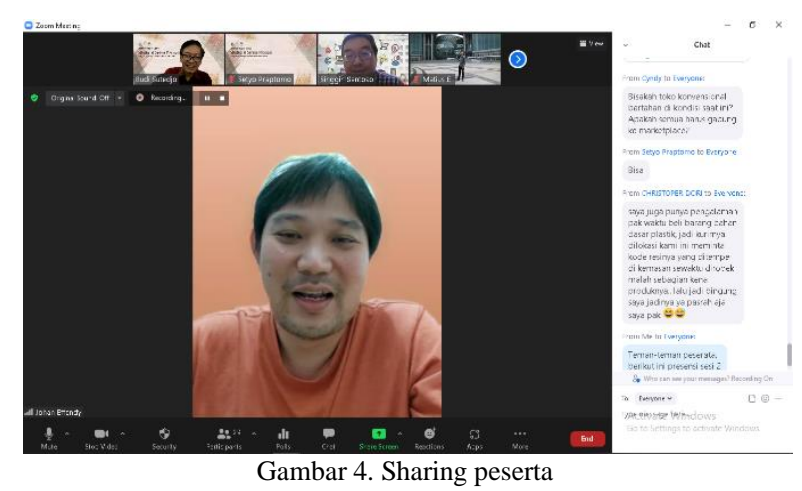

Pengumpulan data dari peserta dilakukan sebanyak 4 kali, terdiri dari a) penjajagan minat peserta dilakukan melalui cara wawancara dengan mitra; b) informasi awal tentang latar belakang peserta dan usahanya dilakukan melalui kuesioner dalam bentuk google form yang diberikan bersamaan dengan formulir pendaftaran; c) respon pertama peserta setelah mendapatkan motivasi, pembelajaran, konsultasi dan bimbingan dari narasumber praktisi melalui kuesioner dalam bentuk google form yang diberikan bersamaan dengan presensi 1; d) respon kedua peserta setelah mendapatkan pembelajaran dari narasumber akademisi melalui kuesioner dalam bentuk google form yang diberikan bersamaan dengan presensi 2 .

Dari data yang diperoleh dilakukan analisis dengan teknik deskriptif untuk mengetahui dan memahami topik pelatihan yang dibutuhkan, bentuk kegiatan dan metode pelatihan yang sesuai dengan karakter peserta.

Kegiatan pengabdian kepada masyarakat ini dilakukan secara online bekerjasama dengan mitra yang secara kelembagaan berdomisili di Yogyakarta. Kerjasama dilakukan mulai dari penjajagan kebutuhan dan peserta, penyusunan materi, perumusan bentuk kegiatan, pemilihan metode untuk pengembangan peserta, pendaftaran, pelaksanaan dan pasca pelaksanaan yang dilakukan dalam kurun waktu 5 bulan.

\section{IV.HASIL DAN PEMBAHASAN}

Animo peserta yang mengikuti kegiatan pelatihan tentang pemilihan strategi dan sarana promosi untuk peningkatan penjualan online tersebut melebihi dari perkiraan sebelumnya yang hanya 10-20 peserta, tetapi peserta yang mengikuti kegiatan tersebut mencapai 31 orang, karena beberapa peserta mengajak rekan-rekannya yang dari luar kota. Selain itu, peserta antusias dalam mengikuti kegiatan yang dikemas dalam bentuk Webinar tersebut. Antusias peserta tampak dari kehadiran mereka dari awal hingga akhir acara (Gambar 5). Selain itu, peserta juga tampak terlibat aktif memanfaatkan kesempatan tanya 
jawab, konsultasi dan bimbingan, serta sharing pengalaman, pemikiran dan rencananya untuk memperoleh tanggapan dan evaluasi dari para narasumber. Peserta mengajukan pertanyaan atau pun berkonsultasi dengan narasumber melalui sarana chat dalam aplikasi Zoom, maupun memanfaatkan giliran untuk sharing secara langsung (Gambar 6).

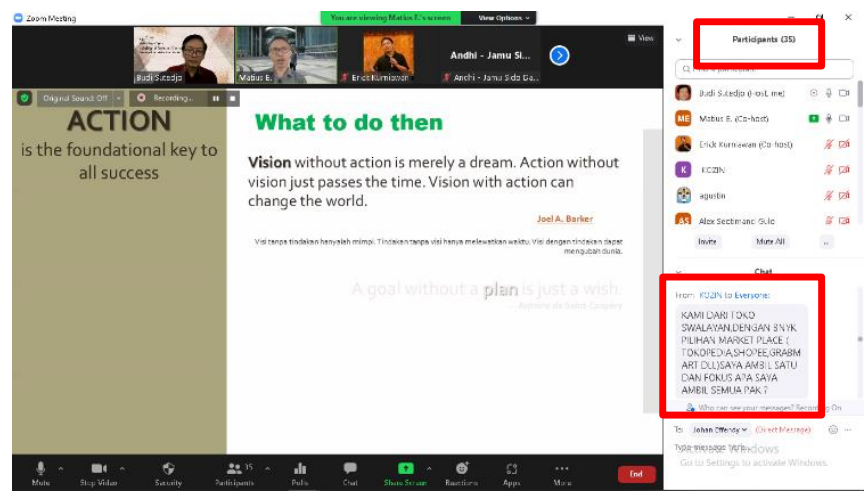

Gambar 5. Total partisipan 35 dan bentuk chat konsultasi (Peserta 31, Narasumber 3, Moderator 1)

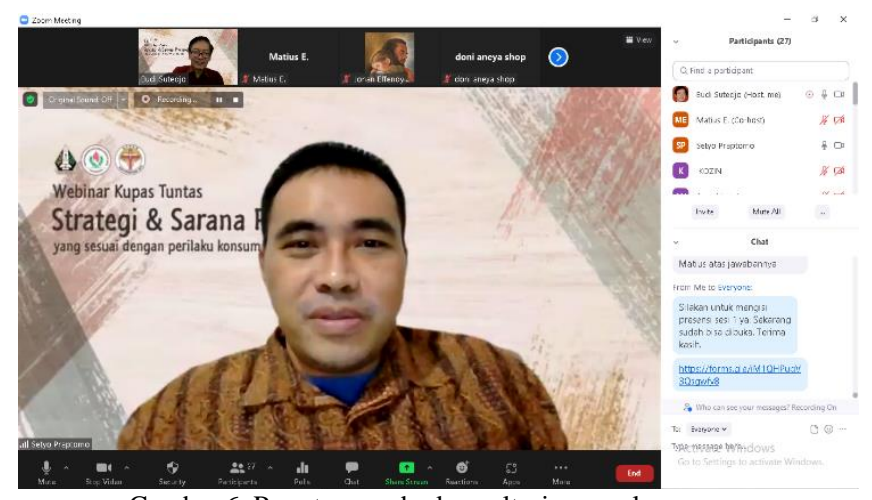

Gambar 6. Peserta yang berkonsultasi secara langsung

Dari kuesioner yang diberikan saat presensi pertama dan kedua dalam kegiatan yang dilangsungkan tersebut, maka dapat diketahui bahwa peserta memperoleh beberapa manfaat, yaitu:

1. Tumbuhnya kesadaran tentang pentingnya rumusan visi dan tujuan yang jelas, serta pengetahuan dan cara untuk mengidentifikasi perilaku konsumen sasaran dalam upaya untuk memilih strategi dan dan menentukan saranasarana promosi yang akan digunakan untuk meningkatkan penjualan online.

2. Tumbuhnya kesadaran tentang pentingnya teori tentang strategi dan penguasaan teknologi informasi untuk mengikuti dan membidik konsumen sasaran dengan tepat.

3. Peserta mendapatkan inspirasi-inspirasi baru tentang potensi konsumen sasaran yang belum dibidik selama ini, penggunaan review dan testimoni konsumen, kerjasama dengan influencer, respon yang cepat, pembentukan komunitas, penguatan merek (brand), memperbanyak penyajian gambar dan video (Tik-Tok) atau animasi, serta penggunaan aplikasi-aplikasi yang diproduksi Microsoft.

Kesulitan utama penyelenggaraan kegiatan ini terjadi saat pemilihan bentuk kegiatan dan waktu pelaksanaan di tengah penerapan PPKM darurat dan level 4 di Yogyakarta yang tidak memungkinkan dilakukannya kegiatan pelatihan secara offline. Kesulitan itu di atasi dengan melakukan komunikasi untuk memotivasi dan menyakinkan lembaga mitra dan calon peserta bahwa kegiatan pelatihan secara online tetap memberi manfaat. Pelatihan pun akhirnya berlangsung dalam bentuk webinar pada tanggal 21 Agustus 2021. Sebagaimana diketahui dari hasil kuesioner, pelatihan yang dilakukan dengan mengkombinasikan antara narasumber praktisi dan akademisi secara daring tersebut dinilai telah menjawab kebutuhan peserta dan mereka memperoleh sejumlah manfaat yang dapat memajukan penjualan online-nya.

Peserta pun berharap pelatihan secara online tersebut dapat dilakukan lagi di masa mendatang. Mereka menuliskannya dalam kuesioner untuk topik-topik yang ingin mereka kuasai, antara lain:

1. Teknik copywriting yang menarik

2. Pengemasan produk

3. Manajemen biaya

4. Cara membangun merek

5. Pembuatan video promosi

\section{KESIMPULAN}

Animo peserta yang tinggi, keaktifan peserta dalam memberikan data dan menjawab kuesioner, keikutsertaan secara penuh dari seluruh rangkaian kegiatan dan berpartisipasi aktif dalam tanya jawab, konsultasi dan sharing menjadi indikator bahwa bentuk kegiatan dan metode pelatihan sesuai dengan harapan mereka. Selain itu, topik dan materi, bentuk kegiatan, metode pelatihan dan narasumber dinilai mampu menjawab kebutuhan peserta untuk meningkatkan kesadaran, pengetahuan, keterampilan dalam memilih strategi dan sarana promosi, serta inspirasiinspirasi baru, khususnya tentang potensi konsumen sasaran yang belum dibidik.

Tumbuhnya keinginan untuk mempelajari sejumlah topik yang diusulkannya menunjukkan bahwa dalam diri mereka telah tumbuh kesadaran tentang pentingnya untuk belajar dan berlatih, agar mereka dapat senantiasa mampu beradaptasi dengan perubahan.

Program pengabdian berupa pelatihan bersama dengan para lembaga mitra ini dapat terus dilanjutkan di kemudian hari dengan mengupas topik-topik sebagaimana telah diusulkan untuk membantu peserta dalam mengatasi 
hambatan-hambatan untuk memajukan penjualan onlinenya.

\section{UCAPAN TERIMA KASIH}

Penulis mengucapkan terima kasih yang sebesarbesarnya kepada LPPM Universitas Kristen Duta Wacana yang telah membiayai pelaksanaan kegiatan pengabdian kepada masyarakat ini.

\section{DAFTAR PUSTAKA}

[1] Masjuli. (2020). Manajemen, Teknologi, \& Komunikasi Keselamatan dan Kesehatan Kerja: Bekerja dengan Aman selama Pandemi Covid-19 Berbasis ISO PAS 45005:2020. Yogyakarta: CV Talenta Indonesia Mandiri.

[2] Kusumo, H. J. (2020, Agustus 3). Ribuan Mahasiswa Meninggalkan Yogyakarta, Begini Dampak Ekonominya. Bisnis.com.

[3] Mustika, S. (2020, Juli 7). Yogyakarta yang sedang Terluka: Corona Datang, Wisatawan Hilang. detikTravel.

[4] Kasali, R. (2017). Distruption. Jakarta: PT Gramedia Pustaka Utama.

[5] Savitri, A. (2019). Revolusi Industri 4.0: Mengubah Tantangan Menjadi Peluang di era Disrupsi 4.0. Yogyakarta: Penerbit Genesis.

[6] Ramdhan, H. E. (2016). Startupreneur: Menjadi Entrepreneur Startup. Jakarta: Penerbit Penebar Luas.

[7] Wardhana, L., \& Makodian, N. (2010). Technopreneur. Jakarta: PT Elex Media Komputindo.

[8] Tapscott, D. (2009). Grown Up Digital: yang muda yang mengubah dunia. Jakarta: PT Gramedia Pustaka Utama.

[9] Viki, T., Toma, D., \& Gons, E. (2019). The Corporate Startup. Jakarta: PT Elex Media Komputindo.

[10] Kunto, G. (2014). Youth Marketing. Jakarta: Penerbit Transmedia.

[11] Kotler, P., Kartajaya, H., \& Huan, H. D. (2017). Marketing for Competitiveness: Asia yang Mendunia pada Era Konsumen Digital. Yogyakarta: PT Bentang Pustaka.

[12] Sanimah, Rambe, I. W., \& Wahyuni, S. (2021). Pemberian Motivasi Daring Lanjut Pendidikan ke Perguruan Tinggi Terhadap Siswa SMA/SMK pada Masa Pandemi di Kelurahan Dendang. Jurnal Abdi, 125-131.

[13] Rosyidi, A. M. (2017). Model dan Strategi Pembelajaran Diklat. Andragogi Jurnal Diklat Teknis, 100-111. 